\title{
PENGARUH KOMPENSASI FINANSIAL TERHADAP KINERJA PEGAWAI
}

\author{
Anindita Kusumawardani, Febri Yuliani, dan Adianto \\ Pascasarjana Ilmu Administrasi FISIP Universitas Riau Pekanbaru
}

\begin{abstract}
This research is quantitative descriptive. The nature of research is descriptive explanatory research. Explanatory research is to describe the position of the examined variables as well as the relationship between variables with other variables. The results showed that the influence of financial compensation on employee performance is in very strong categories. This means that by providing good financial compensation, the employee's performance will be maintained because the employees feel very much appreciated by the organization and the employees think the organisation has tried to the fullest Possible to pay attention to them in the work. At the value of the correlation coefficient found a value of 0.857 so that it belongs to the very strong category. That is, there is a very strong relationship between financial compensation variables and employee performance.
\end{abstract}

\begin{abstract}
Abstrak: Penelitian ini bersifat deskriptif kuantitatif. Sifat penelitian adalah deskriptif explanatory research. Explanatory research yaitu untuk menjelaskan kedudukan variabel-variabel yang diteliti serta hubungan antara variabel dengan variabel yang lain. Hasil penelitian menunjukkan bahwa pengaruh kompensasi finansial terhadap kinerja pegawai berada pada kategori sangat kuat. Hal ini menandakan bahwa dengan adanya pemberian kompensasi finansial yang baik maka kinerja pegawai akan tetap terjaga karena para pegawai merasakan sangat dihargai oleh organisasinya. Selain itu pegawai menganggap organisasi telah berusaha semaksimal mungkin untuk memberikan perhatian kepada mereka dalam bekerja. Pada nilai koefisien korelasi ditemukan nilai sebesar 0,857 sehinga hal ini termasuk pada kategori sangat kuat. Artinya, terdapat hubungan yang sangat kuat antara variabel kompensasi finansial dan kinerja pegawai.
\end{abstract}

Kata kunci: kompensasi finansial, kinerja pegawai, Dinas Pemberdayaan Masyarakat dan Desa

\section{PENDAHULUAN}

Kinerja dan kompensasi memiliki keterkaitan yang mendasar. Kompensasi merupakan faktor yang sangat penting dalam sebuah organisasi. Mathis \& Jackson (2012) mengatakan bahwa kompensasi yang diberikan oleh organisasi memiliki perbedaan-perbedaan yang berarti dalam pembayaran untuk memberi ganjaran kepada karyawan yang berprestasi tinggi dan rendah dengan begitu kompensasi akan mempengaruhi kinerja dari pegawai tersebut. Hal ini juga didukung menurut Simanjuntak (2011) bahwa kompensasi individu menjadi salah satu faktor yang mempengaruhi kinerja pegawai. Pemberian kompensasi tersebut dapat digunakan untuk memotivasi para pegawai di sebuah organisasi. Pemberian kompensasi finansial kepada pegawai, masih dirasakan belum memenuhi tingkat kebutuhan dan kepuasan dari pegawai sesuai tingkat pendapatan yang diterima. Ini tercermin dari banyaknya keluhan pegawai untuk ditingkatkan kompensasinya sesuai dengan tingkat kesejahteraan pribadi dan keluarganya atas pendapatan yang diterima. Banyak pegawai saat ini selalu mendambakan pemberian kompensasi finansial untuk ditingkatkan sesuai dengan kelayakan pemberiannya dengan pekerjaan yang dilakukan, dalam rangka membangun motivasi pegawai untuk dapat bekerja dengan baik dalam melaksanakan tugas pokok dan fungsinya dalam suatu organisasi.

Dinas Pemberdayaan Masyarakat dan Desa (PMD) Provinsi Riau merupakan bagian integral institusi birokrasi pelayanan publik. Berdasarkan Peraturan Gubernur Riau Nomor 76 Tahun 2016 tentang Kedudukan, Susunan Organisasi, Tugas dan Fungsi, Serta Tata Kerja Dinas Pemberdayaan Masyarakat dan Desa Provinsi Riau, Dinas Pemberdayaan Masyarakat dan Desa merupakan unsur pelaksana urusan pemerintahan yang menjadi kewenangan daerah, mempunyai tugas membantu Gubernur melaksanakan Urusan Pemerintahan yang menjadi 
kewenangan Daerah dan Tugas Pembantuan yang ditugaskan kepada Daerah. Dinas Pemberdayaan Masyarakat dan Desa Provinsi Riau telah berupaya untuk mendefenisikan apa yang akan dicapai oleh organisiasi, mengidentifikasikan strategi, memperjelas prioritas organisasi dan bagaimana cara mencapai hasil tersebut. Dengan kata lain perencanaan strategis Dinas Pemberdayaan Masyarakat dan Desa Provinsi Riau ini disusun dalam rangka pemenuhan tugas pokok merumuskan kebijakan dan koordinasi di Bidang Pembinaan Pemerintahan Desa Provinsi Riau. Mencapai visi dan misi tersebut, Dinas Pemberdayaan Masyarakat dan Desa Provinsi Riau selanjutnya menyusun sasaran strategis sebagai penjabaran dan penyelarasan dari Indikator Kinerja Utama (IKU) Pemerintah Provinsi Riau.

Data menunjukkan realisasi kegiatan dari tahun 2017 dan tahun 2018, terjadi peningkatan realisasi dari beberapa kegiatan yang menjadi sasaran strategis Dinas Pemberdayaan Masyarakat dan Desa Provinsi Riau. Namun hal ini belum dapat diasumsikan sebagai peningkatan kinerja karena pada beberapa kegiatan lain seperti meningkatkan infrastruktur dasar sarana prasarana perdesaan, meningkatkan pembangunan resetlement dikawasan kumuh perdesaan dan meningkatkan pengelolaan sumber daya alam berwawasan lingkungan dengan mendayagunakan teknologi tepat guna (TTG) tidak terealisasi. Kinerja sebuah organisasi dikatakan baik jika kinerja para pegawainya juga baik sehingga sebuah organisasi mampu mencapai tujuan organisasi. Di lingkungan Pemerintahan, kinerja pegawai selalu dilihat dari Sasaran Kinerja Pegawai (SKP), dimana SKP ini dibuat oleh pegawai sendiri dan dinilai objektif oleh atasan langsung. Kinerja pegawai dapat dilihat melalui sasaran kinerja pegawai (SKP). Berdasarkan Peraturan Pemerintah Nomor 30 Tahun 2019 tentang Penilaian Kinerja Pegawai Negeri Sipil, Sasaran Kinerja Pegawai adalah rencana kinerja dan target yang akan dicapai oleh seorang Pegawai Negeri Sipil yang harus dicapai setiap tahun. SKP digunakan sebagai pelengkap administrasi pegawai dalam kenaikan pangkat dan penerimaan Tambahan Penghasilan Pegawai
(TPP) di lingkungan Pemerintah Provinsi Riau.

Hal yang dilakukan oleh Pemerintah Provinsi Riau dalam hal memetakan kompetensi pegawai bertujuan untuk memudahkan pegawai dalam melaksanakan tugasnya. Pemetaan kompetensi dilakukan untuk mengetahui sebaran kuantitas dan kualitas kompetensi pegawai. Kemudian seluruh jabatan dievaluasi dan dianalisis untuk selanjutnya ditentukan job grade dari masing-masing jabatan yang akan dikorelasikan dengan pengembangan sistem pengukuran kinerja bagi setiap pegawai. Untuk menghasilkan kinerja organisasi yang optimal dapat diukur dari hasil pekerja yang telah dilakukan dengan standar yang telah ditetapkan, keberhasilan suatu organisasi dipengaruhi oleh kinerja pegawai. Kinerja merupakan suatu hasil kerja yang dicapai oleh pegawai dalam melaksanakan tugas sesuai dengan tanggung jawabnya. Pencapaian kinerja masing-masing individu pegawai maka organisasi dapat mencapai keberhasilan sesuai dengan tujuan suatu organisasi. Data dan informasi itu semua akan digunakan untuk membuat sistem jenjang karir dan sistem pemberian kompensasi, dimana setiap pegawai akan diberikan tambahan penghasilan berupa tunjangan kinerja yang disebut Tambahan Penghasilan Pegawai (TPP).

Fenomena awal terkait belum optimalnya kinerja Pegawai Negeri Sipil (PNS) pada Dinas Pemberdayaan Masyarakat dan Desa Provinsi Riau terlihat dalam hal disiplin kerja. Disiplin kerja merupakan salah satu indikator dalam menentukan kinerja pegawai. Dari disiplin kerja pegawai mampu mempengaruhi jumlah tambahan penghasilan pegawai yang diterima oleh pegawai tersebut. Pegawai yang tidak mengikuti apel pagi tahun 2017 sebanyak 10 orang dan tahun 2018 sebanyak 8 orang. Pegawai yang tidak masuk kantor dan tidak melaksanakan tugas serta pulang kerja tidak sesuai ketentuan pada tahun 2017 sebanyak 18 orang dan tahun 2018 sebanyak 17 orang. Untuk pegawai yang tidak hadir di tempat bekerja tahun 2017 sebanyak 7 orang dan tahun 2018 sebanyak 4 orang. Hal ini masih belum bisa dikatakan memuaskan. Terlihat di tabel masih lumayan banyak pegawai yang setelah apel pagi memilih di luar kantor daripada 
masuk kantor dan melaksanakan tugas sesuai jam kantor. Sehingga tingkat pencapaian kinerja pegawai menjadi terhambat. Pada tahun 2018 terlihat tren sedikit menurun tapi tidak signifikan karena telah menggunakan sistem absen finger print, hal ini perlu menjadi perhatian bagi pimpinan.

Tingkat kehadiran Pegawai dan penilaian Sasaran Kinerja Pegawai (SKP) dipergunakan sebagai dasar pembayaran Tambahan Penghasilan Pegawai (TPP) dengan kriteria penilaian $60 \%$ (enam puluh persen) dari capaian kinerja pegawai dan $40 \%$ dari penilaian perilaku kerja pegawai setiap bulannya. Suatu fenomena yang dapat dicontohkan mengenai pemberian kompensasi finansial adalah gaji, tunjangan dan insentif yang berdampak terhadap kinerja yang dilakukan oleh pegawai. Apabila terpenuhi pemberian kompensasi finansial, secara langsung memberikan pengaruh terhadap kinerja, jika tidak tentu akan menurunkan kinerja pegawai.

Griffin (2004) mendefinisikan kompensasi sebagai suatu bagian penting dan kompleks dalam hubungan karyawan dalam organisasi. Kompensasi dasar diperlukan untuk mempertahankan karyawan dengan standar hidup yang layak. Akan tetapi kompensasi juga menyediakan suatu pengukuran berwujud mengenai nilai individu bagi organisasi. Pemberian kompensasi merupakan fungsi strategik sumber daya manusia yang mempunyai imbas signifikan atas fungsifungsi sumber daya manusia lainnya.

Kompensasi adalah hak-hak pegawai yang harus diterima sebagai imbalan atau kompensasi setelah mereka menjalankan kewajibannya. Kompensasi dibagi menjadi dua, yaitu:

\section{Kompensasi Finansial}

Kompensasi finansial adalah kompensasi yang diterima dalam bentuk uang dan dapat diuangkan, yang terdiri dari kompensasi langsung dan kompensasi tidak langsung.

\section{a. Kompensasi langsung}

Menurut Hariandja (2002) kompensasi langsung adalah kompensasi yang dikaitkan secara langsung dengan pekerjaan seperti upah atau gaji dan bonus. Gaji atau upah menurut Hariandja (2002) adalah balas jasa dalam bentuk uang yang diterima karyawan sebagai konsekuensi dalam kedudukannya sebagai seorang pegawai yang memberikan sumbangan pikiran dalam mencapai tujuan organisasi. Marihot (2002) menyatakan bahwa gaji merupakan pembayaran tetap yang diterima seseorang dari anggotanya dalam sebuah organisasi. Berdasarkan pendapat di atas, dapat disimpulkan bahwa gaji merupakan suatu balas jasa berupa uang yang diberikan oleh organisasi kepada pegawainya tanpa melihat hasil kerja yang dicapai. Besarnya gaji tetap tidak berubah sesuai dengan golongan dan pangkatnya dan tidak berdasarkan jam kerja yang diberikan setiap bulan atau setiap minggu. Sedangkan bonus pada umumnya diartikan sebagai pemberian pendapatan tambahan bagi karyawan atau pekerja yang diberikan setahun sekali atau pada waktu tertentu, bila syarat tertentu pula dipenuhi. Simamora (2006) menjelaskan bahwa bonus adalah tambahan kompensasi diluar gaji atau upah yang diberikan oleh organisasi. Program bonus disesuaikan dengan memberikan bayaran tambahan berdasarkan produktivitas, keuntungan, jumlah kehadiran, prestasi kerja, produktivitas pegawai, dan efektivitas biaya. Kompensasi langsung diantaranya terdiri dari bayaran pokok terdiri dari gaji dan upah, bayaran prestasi, bayaran insentif terdiri dari bonus, komisi, pembagian laba dan pembagian saham, dan bayaran tertangguh merupakan program tabungan anuitas pembelian saham.

\section{b. Kompensasi tidak langsung}

Simamora (2006) menjelaskan bahwa kompensasi tidak langsung atau tunjangan sebagai pembayaran dan jasa yang melindungi serta melengkapi gaji pokok dan perusahaan membayar semua atau sebagian dari tunjangan ini. Kompensasi tidak langsung, diantaranya program perlindungan terdiri atas asuransi jiwa, asuransi kesehatan dan asuransi tenaga kerja, bayaran diluar jam kerja terdiri atas liburan, cuti tahunan dan libur hari besar dan fasilitas terdiri atas kendaraan, tempat parkir, kakntin dan tempat beribadah.

Suatu organisasi baik itu pemerintah maupun swasta yang terdiri dari sekelompok orang yang berperan aktif untuk mencapai tujuan yang ingin dicapai dari organisasi tersebut. Tujuan organisasi tidak akan tercapai jika kinerja ang- 
gota atau pegawainya tidak maksimal. Fahmi (2011) menyatakan kinerja adalah hasil yang diperoleh oleh suatu organisasi baik organisasi tersebut bersifat profit oriented dan non profit oriented yang dihasilkan selama satu periode waktu. Mangkunegara (2002) menjelaskan kinerja merupakan hasil kerja secara kualitas dan kuantitas yang dicapai oleh seseorang dalam melaksanakan fungsinya sesuai dengan tanggung jawab yang diberikan kepadanya. Sutrisno (2010) menggambarkan bahwa kinerja merupakan kuantitas, kualitas dan waktu yang digunakan dalam menjalankan tugas. Kuantitas adalah hasil yang dapat dihitung sejauh mana seseorang dapat berhasil mencapai tujuan yang telah ditetapkan. Kualitas adalah bagaimana seseorang dalam menjalankan tugasnya, yaitu mengenai banyaknya kesalahan yang dibuat, kedisiplinan dan ketepatan. Waktu kerja adalah mengenai jumlah absen yang dilakukan, keterlambatan dan lamanya masa kerja dalam tahun yang telah dijalani. Sehingga dapat disimpulkan kinerja pegawai merupakan hasil kerja pegawai dilihat dari aspek kualitas, kuantitas, waktu kerja dan kerja sama untuk mencapai tujuan yang sudah ditetapkan oleh organisasi.

Keban (2004) menjelaskan pengukuran kinerja pegawai penting dilakukan oleh instansi pelayanan publik. Dengan mengetahui kelemahan dan kelebihan, hambatan dan dorongan, atau berbagai faktor sukses bagi kinerja pegawai serta institusi maka terbukalah jalan menuju profesionalisasi, yaitu memperbaiki kesalahan-kesalahan yang dilakukan selama ini. Indikator kinerja menurut Swanson dan Holton yang dikutip oleh Keban (2004) mengemukakan bahwa kinerja pegawai secara individu dapat dilihat dari apakah misi dan tujuan pegawai sesuai dengan misi lembaga, apakah pegawai menghadapi hambatan dalam bekerja dan mencapai hasil, apakah pegawai mempunya kemampuan mental, fisik, emosi dalam bekerja dan apakah mereka memiliki motivasi yang tinggi, pengetahuan, keterampilan dan pengalaman dalam bekerja. Schuler dan Dowling dalam Keban (2004) Kinerja dapat diukur dari :

a. Kuantitas kerja

b. Kualitas kerja c. Kerjasama

d. Pengetahuan tentang kerja

e. Kehadiran dan ketepatan waktu

f. Inisiatif dan penyampaian ide-ide yang sehat

Kinerja pegawai dan kinerja organisasi memiliki keterkaitan yang erat, tercapainya tujuan organisasi tidak bisa dilepaskan dari sumber daya yang dimiliki oleh organisasi yang dijalankan pegawai yang berperan aktif sebagai pelaku dalam upaya mencapai tujuan organisasi. Berdasarkan beberapa teori diatas peneliti menyimpulkan bahwa kinerja pegawai adalah penilaian hasil kerja seseorang dalam suatu organisasi sesuai dengan tugas dan tanggungjawabnya dalam rangka mencapai tujuan organisasi.

Tujuan penelitian ini untuk mengetahui dan menganalisis pengaruh kompensasi finansial terhadap kinerja pegawai di Dinas Pemberdayaan Masyarakat dan Desa Provinsi Riau.

\section{METODE}

Jenis penelitian ini adalah penelitian kuantitatif dengan pendekatan survey yang bersifat deskriptif yang bertujuan untuk menggambarkan dan mengungkapkan suatu masalah, keadaan, peristiwa sebagaimana adanya, serta mengungkapkan fakta secara lebih mendalam mengenai pengaruh kompensasi finansial terhadap kinerja pegawai. Sampel penelitian yang terpilih sebanyak 44 orang yang berasal dari pegawai pada Dinas Pemberdayaan Masyarakat dan Desa Provinsi Riau. Pengumpulan data dilakukan dengan menggunakan kuisioner yang disebarkan kepada setiap sampel yang sudah ditetapkan. Skala pengukuran penelitian ini menggunakan skala likert untuk mengetahui skor pertanyaan. Skala Likert merupakan skala yang dipakai untuk mengukur sikap, pendapat, dan persepsi seseorang/kelompok orang tertentu fenomena sosial.

Analisis data dilakukan dengan uji statistic, dengan menggunakan pengujian diantaranya: Pertama, Uji validitas yang digunakan untuk mengukur sah atau tidaknya suatu kuesioner. Kedua, Uji reliabilitas dimaksudkan untuk menguji sejauh mana hasil pengukuran tetap konsisten, apabila dilakukan pengukuran dua kali atau lebih terhadap gejala yang sama dengan alat ukur yang sama. Ketiga, Uji korelasi product 
moment digunakan untuk mencari hubungan dan membuktikan hipotesis hubungan dua variabel bila data kedua variabel berbentuk interval atau ratio, dan sumber data dari dua variabel atau lebih adalah sama.

\section{HASIL DAN PEMBAHASAN Uji Validitas}

Untuk mengetahui apakah instrumen butirbutiritem telah memiliki tingkat kesahihan (validitas) dan tingkat keterandalan (reabilitas), maka perlu diadakan uji coba. Ketentuan yang diterapkan dalam penentuan kesahihan dan keterandalan instrumen dalam penelitian ini adalah, apabila Rhitung> R-tabel pada batas signifikansi $5 \%$. Hasil uji validitas variabel diperoleh hasil pengujian instrument variabel kompensasi finansial secara keseluruhan memiliki nilai Corrected Item Total Correlation yang lebih besar dari 0,30. Dengan demikian dapat disimpulkan bahwa seluruh instrument pernyataan dari variabel kompensasi finansial yang digunakan adalah valid dan instrumen ini dapat digunakan dalam penelitian, selain itu hal ini juga diperkuat oleh nilai signifikansi seluruh instrumen yang lebih kecil dari nilai sebesar 5 persen.

Sementara itu untuk hasil pengujian validitas instrumen variabel kinerja pegawai diperoleh bahwa hasil pengujian instrumen dari variabel kinerja pegawai pada Dinas Pemberdayaan Masyarakat dan Desa Provinsi Riau memiliki nilai yang lebih besar dari 0.30. Dengan demikian dapat disimpulkan bahwa seluruh instrumen pertanyaan dari variabel kinerja pegawai pada Dinas Pemberdayaan Masyarakat dan Desa Provinsi Riau yang digunakan adalah valid dan dapat digunakan dalam penelitian. Kesimpulan ini diperkuat dengan nilai signifikansi seluruh instrumen yang lebih kecil dari nilai sebesar 5 persen.

\section{Uji Reliabilitas}

Reliabilitas adalah untuk mengukur suatu kuisioner yang merupakan indikator dari variabel. Suatu kuisioner dinyatakan reliabel atau handal jika jawaban dari responden terhadap pertanyaan adalah konsisten atau stabil dari waktu ke waktu. Pengukuran reliabilitas dapat dilakukan dengan 2 (dua) cara, yaitu: 1) Pengukuran ulang (repeted measure) dengan cara memberikan kuesioner yang sama pada waktu yang berbeda kemudian dilihat apakah responden tetap konsisten dengan jawabannya, dan 2) Pengukuran sekali saja (One Shot) dengan cara hanya sekali saja memberikan kuesioner dan hasilnya dibandingkan dengan mengukur korelasi antar jawaban pertanyaan. Pengujian reliabilitas kuesioner dalam penelitian ini dengan menggunakan pengukuran sekali saja (One Shot) dan untuk pengujian reliabilitasnya digunakan uji statistik Gronbach Alpha > 0,6.

Berdasarkan Tabel 1 diperoleh bahwa hasil pengujian seluruh variabel penelitian memiliki nilai r-hitung > r-tabel (0.60). Dengan demikian dapat disimpulkan bahwa seluruh instrumen pertanyaan tentang variabel penelitian kompensasi finansial dan kinerja pegawai adalah reliable sehingga seluruh item pertanyaan layak dipergunakan dalam penelitian.

\section{Uji Korelasi Product Moment}

Untuk mengetahui tingkat hubungan antara kompensasi finansial dengan Kinerja pegawai di Dinas Pemberdayaan Masyarakat dan Desa Provinsi Riau, atau hubungan variabel bebas (X) dengan variabel terkat (Y), maka digunakan analisa korelasi. Dalam penelitian ini, teknik analisa data yang sudah diperoleh dari hasil penelitian di lapangan adalah dengan menggunakan rumus koefisien product moment sebagai berikut :

Tabel 1. Hasil Uji Reliabilitas Variabel Penelitian

\begin{tabular}{cccccc}
\hline Variabel & $\begin{array}{c}\text { Scale Mean } \\
\text { if Item } \\
\text { Deleted }\end{array}$ & $\begin{array}{c}\text { Scale } \\
\text { Variance if } \\
\text { Item Deleted }\end{array}$ & $\begin{array}{c}\text { Corrected Item- } \\
\text { Total } \\
\text { Correlation }\end{array}$ & $\begin{array}{c}\text { Cronbach's } \\
\text { Alpha if Item } \\
\text { Deleted }\end{array}$ & Keterangan \\
Kemampuan Kerja $(X)$ & 95,9000 & 137,197 &, 885 &, 842 & Reliabel \\
Kinerja Pegawai $(Y)$ & 107,6333 & 161,206 &, 821 &, 855 & Reliabel \\
\hline
\end{tabular}




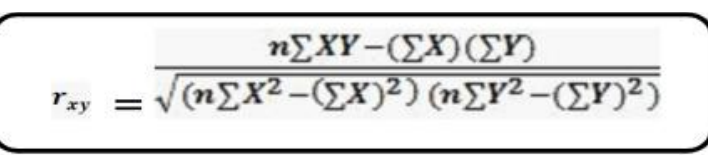

Berdasarkan data hasil penelitian yang diolah diperoleh hasil sebagai berikut:

$$
\begin{aligned}
\mathrm{N} & =44 \\
\sum \mathrm{x} & =1.516 \\
\sum \mathrm{y} & =1.901 \\
\sum \mathrm{x} 2 & =52.789 \\
\sum \mathrm{y} 2 & =83.565 \\
\sum \mathrm{xy} & =65.975
\end{aligned}
$$

Selanjutnya hasil tersebut dimasukkan kedalam rumus product moment, maka diperoleh hasil sebagai berikut:

$$
\begin{aligned}
& r_{x y}=\frac{n \sum X Y-\left(\sum X\right)\left(\sum Y\right)}{\sqrt{\left(n \sum X^{2}-\left(\sum X\right)^{2}\right)\left(n \sum Y^{2}-\left(\sum Y\right)^{2}\right)}} \\
& r_{x y}=\frac{44.65975-(1516)(1901)}{\sqrt{[44.52789(1.516) 2][(44.83565-(1901) 2]}} \\
& r_{x y}=\frac{2902900-2881916}{\sqrt{[2322716-2298256][(3676860-3613801]}} \\
& r_{x y}= \\
& r_{x y}=\frac{20984}{\sqrt{124460][63059]}} \\
& r_{x y}=\frac{20984}{1542423} \\
& r_{x y}=0,857
\end{aligned}
$$

Hasil perhitungan koefisien korelasi tersebut adalah 0.857 , nilai r yang diperoleh adalah positif $(r=+)$. Hal ini menunjukkan bahwa hubungan antara kedua variabel positif, hal ini berarti ada pengaruh antara kompensasi finansial dan kinerja pegawai. Dengan hasil perhitungan yang positf, mengartikan bahwa kenaikan variabel yang satu akan diikuti kenaikan variabel lainnya dan kedua variabel memiliki hubungan yang positif (Sugiyono, 2010). Maka semakin baik kompensasi finansial yang diterima oleh pegawai, maka kinerja yang dihasilkan pun maksimal.

Berdasarkan pedoman yang diberikan diatas, maka koefisien korelasi yang ditemukan sebesar 0,857 termasuk padakategori sangat kuat. Artinya, terdapat hubungan yang sangat kuat antara variabel kompensasi finansial dan kinerja pegawai.

\section{SIMPULAN}

Dinas Pemberdayaan Masyarakat dan Desa Provinsi Riau dalam usaha memberikan kesejahteraan kepada para pegawainya maka terkait pemberian kompensasi finansial harus dilakukan dengan standar yang jelas dan waktu yang tepat karena selama ini ada kecenderungan pemberian kompensasi finansial kepada pegawai seperti pembayaran TPP setiap bulannya selalu tidak tepat waktu sehingga membuat pegawai menjadi kurang bergairah dalam bekerja. Kemudian dalam usaha melakukan peningkatan kinerja para pegawainya, maka Dinas Pemberdayaan Masyarakat dan Desa Provinsi Riau agar lebih memikirkan kesejahteraan pegawai berupa pemberian insentif kepada pegawainya yang diberikan berdasarkan kemampuan kerja individu dari pegawai dan juga memperhatikan kenyamanan pegawai dalam jangka panjang selama berada di tempat kerja dan memberikan pelatihan dan pendidikan yang berguna untuk meningkatkan prestasi pegawai dalam mencapai kinerja pegawai yang diharapkan.

\section{DAFTAR RUJUKAN}

Muljani, Ninuk. 2002. "Kompensasi Sebagai Motivator untuk Meningkatkan Kinerja Karyawan". Jurnal Manajemen dan Kewirausahawan Vol. 4 No. 2.

Masrukin dan Waridin. 2006. “Pengaruh Motivasi Kerja, Kepuasan Kerja, Budaya Organisasi dan Kepemimpinan terhadap Kinerja Pegawai". Jurnal Ekonomi \& Bisnis, Vol.7, No. 2.

Sigid, A Saputra, 2010, Pengaruh Kompensasi, Kepuasan Kerja dan Motivasi Terhadap Kinerja Karyawan Bagian Akuntansi Pada Perusahaan Umum di Surabaya dan Sidoarjo. STIE Perbanas.

Simanjuntak, Payaman J. 2011. Manajemen dan Evaluasi Kinerja. Jakarta: Fakultas Ekonomi Universitas Indonesia

Sinambela, Lijan Poltak. 2019. Manajemen Sumber Daya Manusia. Jakarta : Bumi Aksara

Suwatno dan Donni Juni Priansa. 2011. Manajemen SDM dalam Organisasi Publik dan Bisnis. Bandung: Alfabeta 